\title{
Accounting
}

\section{Determinants of accounting information systems quality: Empirical evidence from Vietnam}

\author{
Hieu Thanh Nguyen ${ }^{a^{*}}$ and Anh Huu Nguyen ${ }^{a}$
}

${ }^{a}$ National Economics University, Vietnam

\begin{tabular}{l}
\hline C H R O N I C L E \\
\hline Article history: \\
Received September 22019 \\
Received in revised format \\
September 22019 \\
Accepted October 152019 \\
Available online \\
October 172019 \\
\hline Keywords: \\
Accounting information systems \\
Quality \\
Explanatory factor analysis \\
Vietnamese enterprises \\
\hline
\end{tabular}

\section{A B S T R A C T}

\begin{abstract}
This research is conducted to investigate the factors affecting the accounting information systems quality. Data was collected by using questionnaire delivered to 347 participants who are board of director's members and managers. The statistical methods approaches are employed to address the research issues including Explanatory Factor Analysis (EFA) and Ordinary Least Squares (OLS). The findings showed that various factors had significant impacts on the accounting information systems quality including (i) organization culture, (ii) manager participation, (iii) information technology, (iv) information technology knowledge of managers, (v) accounting knowledge of managers, (vi) accounting information applications, (vii) consultation of external experts and (viii) training activities for users in accounting information systems. Based on the research results, some key intuitive recommendations were proposed aiming to improve the accounting information systems quality of Vietnamese Enterprises.
\end{abstract}

\section{Introduction}

Accounting information system is a system to collect, record, store and process the data to generate useful information for decision makers. Accounting information system (AIS) involves human components and equipment components such as hardware, software, procedures, databases, and network communication which are designed to alter financial data and nonfinancial data into information to be communicated to various decision makers (Bodnar \& dan Hopwood, 2010; Romney \& Steinbart, 2015; Wilkinson, 2000). Quality of Accounting information system is presented when the system is capable of exploiting existing resources at the unit to provide reliable, flexible, integrated, and easily accessible financial and non-financial information and timely (Ong et al., 2009; Wixom \& Todd; 2005); brings efficient and effective performance to the company ( Kaplan \& Atkinson, 1998); helpful for managers to make optimal decisions that help businesses achieve their goals (Napitupulu, 2018). Factors affecting the quality of accounting information systems have attracted the attention of scholars in countries around the world (Gullkvist, 2002; Ismail \& King, 2007; Sajady et al., 2008; Ismail, 2009; Grande et al., 2010; Kharuddin et al., 2010; Kouser et al., 2011; Rapina, 2014; Fitrios, 2016). However, the research conducted so far has not systematically studied the full range of factors that affect AIS quality and researchers have not yet agreed which factors that have the most impact on the quality of accounting information system. Therefore, more research is needed on investigating factors affecting the quality of accounting information systems to supplement empirical testimony on this issue, especially in Vietnam because this issue has hardly been studied in Vietnam in recent years. This study is useful for business managers to help them understand the factors affecting the quality of accounting information systems, thereby improving the quality of accounting information systems and business performance. The remainder of the paper is structured as follows: In Section 2, Literature Review; the next section demonstrates Research Hypotheses; Section 4, presents the Research Methodology; Results and

* Corresponding author.

E-mail address: hieu39ktqd@gmail.com (H. Thanh Nguyen) 
Discussion about the factors affecting accounting information systems quality are presented in Section 5 . Finally, the conclusion and recommendations are explained in Section 6.

\section{Literature Review}

\subsection{Accounting Information System}

Romney et al. (2015) state that the accounting information system as a system is to collect, record and process data to produce information for decision-making. O'Brien (2004), Azhar Susanto (2008) defined accounting information systems as a collection of components of both physical and non-physical which are interconnected and cooperate with each other in harmony to process the transaction data related to financial issues into financial information. The accounting information system has a component consisting of hardware, software, brain ware, procedures, database and technology of communication network (Azhar Susanto, 2008). Piccoli (2008) says that a good information system has four components: information technology, people, processes and structures. All these components can be grouped into two subsystems: the technical subsystem and the social subsystem. Accounting system, in recent times, has tended to be a system of information that does not stop at limits of data and financial information, but it includes data and descriptive and quantitative information which is useful in decision making for users distinct with plurality and diversity (Nwinee et al., 2016).

\subsection{Quality of Accounting Information System}

According to Choe (1998), quality of accounting information systems can be analysed on three bases: information scope, timeliness and aggregation. Information scope is considered as financial and nonfinancial information, internal and external information that is useful in prediction of future events. Timeliness quality is related to the ability of accounting information system to satisfy information needed by providing systematic reports to the user. Aggregation of information is considered as means of collecting and summarizing information within a given time period. The criteria for measuring the quality of accounting information are quite diverse. Ong et al. (2009) and Wixom and Todd (2005) used the dimensions of reliability, flexibility, integration, accessibility and timeliness. Chang et al. (2012) measured the quality of information system with security, ease of use and efficiency. Heidmann et al. (2008) measured the dimensions of the quality of management accounting information system using integration, flexibility, accessibility, formalization and media richness. Stair and Reynolds (2010) described generally the characteristics of the quality of information system which are flexible, efficient, accessible and timely. Specifically, Napitupulu (2018) considered the quality of management accounting information system in the form of integration, flexible, reliability and efficient. Quality of accounting information system can be evaluated by its impacts on quality of accounting information, improvement of decision-making process, evaluation of organisation performance, effectiveness of internal controls and facilitating company's transactions (Sajady et al., 2008). Recently, studies have begun to examine whether different organizations' AIS design systematically could support company's chosen strategy. Financial managers need the financial and accounting data provided by AIS to evaluate the firm's past performance and to map future plans. By adopting accounting information system, firm performance can be improved. Grande et al. (2010) discovered a positive association between AIS and organizational performance. Thapayom and Ussahawanitchakit (2015) examined the effect of accounting information system excellence on goal achievement via the mediating influences which include financial reporting efficiency, best accounting practice, and accounting information quality. Data was collected from 152 firms in information and communication technology businesses in Thailand by questionnaire mail survey and key informant was accounting executives. The statistics used to analyse was the ordinary least square regression. The results of OLS regression revealed that three of the four dimensions of AIS excellence had significant positive influence on accounting outcomes, and accounting outcomes had significant positive influence on goal achievement. Alnajjar (2016) analysed the impact of accounting information systems on performance management and organizational performance. Based on the results this study concluded that accounting managers' knowledge and top management support significantly impact on the accounting information systems in an organization and, consequently, accounting information systems also significantly impact the performance management and organizational performance of that organization. By using accounting information systems, decision makers obtain useful information and use it in decision-making and strategy building to achieve organizational goals and objectives, which should increase the company's performance. The research results from Rehab (2018) indicated that: using AIS might be seen as a strong predictor of the organizational performance, coinciding with previous findings (Soudani, 2012; Nabizadeh \& Omrani, 2014). Regarding the cost reduction, the results show that AIS had a positive and significant influence on cost reduction coinciding with previous findings in the literature (Hla \& Teru, 2015). Finally, the research revealed that using AIS can enhance the effectiveness of decision making, which agrees with the study of Onaolapo and Odetayo (2012). 


\subsection{Organisation Culture}

The culture of a group is a pattern of assumptions learned by a group to solve problems of external adaptation and internal integration is carried out for consider and then introduced at organization members (Schein, 2010). Organizational culture from the perspective of information system, Laudon and Laudon (2012) gave definition that organizational culture is a powerful unifying force that restrains political conflict and promotes common understanding, agreement on procedures, and common practices. While discussing the cultural organization, there are two major things that can be used as a basis. First, the values which are shared, important beliefs and goal shared by most people in the group, which tends to shape the behaviour of the group. Second, the group behaviour norm, how to act which is already prevalent or pervasive found in one group and survives long because the group members tend to behave in a way to teach the practice to new members. Research by Rapina (2014) indicated that organizational culture affects the quality of accounting information systems. The relationship between management commitment, organizational culture and organizational structure and quality of accounting information systems are emphasized and management commitment, organizational culture and organizational structure have impact on the quality of accounting information. The quality of accounting information systems can be improved through increased organizational culture, management commitment and organizational structure.

\subsection{Information Technology}

According to Huber (1990), use of advanced information technology (IT) leads to more available and more quickly retrieved information including external information, internal information and thus leads to increased information accessibility. Moreover, Chan et al. (1997) and Hussin et al. (2002) found that an appropriate level of IT sophistication was associated with the capability to align IT strategy and business strategy. Haddad and Atmeh (2009) studied IT affecting the role of accounting information system in decision making strategy in Jordanian industrial companies. The researchers distributed 114 questionnaires to key officers in the Jordanian industrial companies e.g. the CEO, financial managers, production and marketing managers. The statistical method used by them was t-test, spearman correlation, $\mathrm{R}$ square to study the studies hypothesis. Their findings showed that there is a positive relationship between information technology and accounting information system. Ismail and King (2007) investigated a sample of Malaysian manufacturing SMEs. Dimensions of IT sophistication adopted from Raymond and Pare (1992) include: Wordprocessing package, Spreadsheet package, Database package, Accounting-based applications, Computer-assisted production management, local network, external network. The data was collected through a mail questionnaire survey carried out from August to October 2005 such as computer-aided design, computer-aided manufacturing and computerassisted production management. Their findings from their analysis proposed no association between IT sophistication and AIS alignment. Tamoradi (2014) detected factors influencing the AIS alignment (AIS requirements and the AIS capacity) for firms in manufacturing sector listed on Tehran Stock Exchange (Iran). The research sample consists of 216 companies over the period from 2007 to 2011. The results have provided insignificant support for the relationship between IT sophistication and AIS alignment.

\subsection{Accounting Information Applications}

AIS applications portfolio adopted by firms include General ledger, billing, budgeting, order entry, project management, purchasing, cost accounting, production variances, inventory, budget variances, production planning and control, financial analysis. Ismail (2009) examined AIS effectiveness and its influence factors in the specific context of small and medium manufacturing enterprises (SMEs) in Malaysia. The proposed model including 232 SMEs registered with the Federation of Malaysian Manufacturers (FMM). The respondents were asked to indicate whether they adopt or not eighteen AIS applications. To measure the level of AIS applications, application score was created to represent the number of applications adopted by the responding companies. The values of AIS applications range from 1 to 18 . However, Ismail (2009) concluded that AIS sophistication appeared insignificant in this study. The insignificant result of the relationship between AIS sophistication and AIS effectiveness is rather unexpected. Tamoradi (2014) detect factors influencing the alignment of accounting information systems for firms in manufacturing sector listed on Tehran Stock Exchange. The research sample consists of 216 companies over the period 2011-2007. This study has provided significant support for the relationship between Accounting Information System applications and AIS alignment

\subsection{Manager Participation}

AIS implementation requires substantial investment and has an impact on the whole organization. Managers have the authority to ensure sufficient allocation of resources and create a more conducive environment for AIS implementation. In addition, managers' participation in AIS implementation would encourage users to develop positive attitudes towards the use of AIS and thus contributes to a smoother work transition from non-use of AIS to the use of AIS (Thong et al., 
1996). Furthermore, empirical evidences (Igbaria et al., 1997; Foong, 1999; Guinea et al., 2005) have demonstrated that management commitment was positively associated with the perceived ease of use and perceived usefulness of AIS within small and medium sized enterprises (SME). Hussin et al. (2002) and Ismail (2009) measured manager participation in AIS implementation. Based on bipolar anchors with a five-point scale anchored between no participation and high participation, the respondents were asked to indicate their level of participation in the following five areas: definition of needs (information requirements), selection of hardware and software, implementation of systems, systems maintenance and problem solving, and planning for future AIS deployment. The results of Ismail (2009) showed that manager participation in AIS implementation appeared insignificant. Tamoradi (2014) indicated that: in addition to knowledge, an owner/manager's participation and manager commitments also plays essential role in the effectiveness of information system implementation in SMEs. Due to their dominant roles, manager commitment can bring AIS into alignment with the firm's objectives and strategies. However, the results from this study find very little support for the hypothesis, which proposed a relationship between owner/manager commitment and AIS alignment. Alnajjar (2016) investigated the impact of top management support on accounting information systems. The data collected from 74 SMEs related to the trading, services and manufacturing sectors in UAE. SPSS and AMOS are used for doing regression analysis; specific structural equation modelling is applied for data analysis. Based on the results this study concluded that top management support significantly impacted on the accounting information systems.

\subsection{Knowledge of Accounting of Manager}

Knowledge in accounting system as one of the crucial factors influencing data quality in AIS will help organizations enhance their AISs data quality. Ismail and King (2007) stated that managers with both AIS and accounting knowledge are in a better position than those without the knowledge. Asserted by Saeidi (2014) in India that there is a positive relationship between knowledge in accounting and understanding of managers and accountants, decision making, financial performance and organizational resources, suggesting that AIS influences the variable. Alnajjar (2016) investigated the impact of accounting managers' knowledge on accounting information systems. This study analysed the data collected from 74 SMEs in UAE and concluded that accounting managers' knowledge significantly impact on the accounting information systems in an organization.

\subsection{Knowledge of IT of Managers}

Owner or manager's IT knowledge can determine the success or failure of computerization projects because they play a dominant role in an SME's business decisions (Hussin et al., 2002). Most often, the owner/manager of the firm is the only person who fully understands the objectives and directions of the firm. Therefore, owners/managers who are aware of existing and new technologies could be capable of choosing the right software for their firms (Hussin et al. 2002; Ismail \& King, 2007). In the context of AIS, owners/managers with both IT and accounting knowledge are in a better position than those without this knowledge. The reason is because they are able to understand the firm's AIS requirements and then use their IT knowledge to determine the IT deployment, which fits the firm's information needs. Therefore, it is expected that in organizations wherein the owner/manager possesses enough IT and accounting knowledge, there will be a higher degree of AIS alignment. Tamoradi (2014) provided support for the hypothesis, which proposed a relationship between manager IT knowledge with AIS alignment. Managers in the sample SMEs believe they possess a good knowledge of e-mail and Internet and their knowledge of email and the Internet was somehow higher than other IT applications. An independent-samples t-test was then applied to investigate the relationship between alignment groups and knowledge variables. The results indicate that only the owner/manager's knowledge of more sophisticated software contributes to AIS alignment.

\subsection{Training for users}

Training is a process undertaken to acquire and improve employee skills and performance. Training is required for employees to keep up with the application of company rules, such as internal control rules (Hurt \& Zhen, 2008). The training can include any program related to improving the employee skills, including general, technical, interpersonal and problem-solving skills (Robbins \& Judge, 2011). The User Training can be viewed from several sources such as inhouse training, self-study using tutorials, and self-study using manuals and printed documents (Hurt \& Zhen, 2008). Stair and Reynolds (2012) stated that the user training is the key for getting the most out of the accounting information system. Training is not only related to activities such as data entry, but also involves all aspects of the use of new information systems, so that the users (managers and end users) should be educated how new technologies affect the company's operations and business management. Fitrios (2016) aimed to determine the effect of user training on the implementation of accounting information systems. This study was conducted at hospitals type A, B and C in the region of Riau Province, Indonesia. The number of hospitals that fulfil the criteria to have the accounting information system for 42 hospitals. 
The result showed that user training affected the accounting information system implementation at hospitals type A, B, and $\mathrm{C}$ in the province of Riau.

\subsection{Experts Consulting}

One key factor contributing to the quality of AIS implementation is the involvement of external AIS experts including suppliers and consultants (Igbaria et al., 1997; Guinea et al., 2005). However, Yap and Thong (1997) argued that government assistance, in addition to suppliers and consultants, accounting firm also played an equally important role in accelerating AIS adoption among SMEs. Furthermore, Davis (1997) posited that accounting firms are an alternative but equally important source of advice on AIS adoption for SMEs. His argument is supported by Breen and Sciulli (2002), Hartcher (2003), Berry et al. (2006). These studies found accountants, accounting profession, industry associations and AIS training professionals played important roles in encouraging SMEs to computerize their accounting systems. Advice offered by these external experts enable SMEs to gain a broader perspective of both their information needs and information processing capacity. Ismail (2009) concluded that there is a positive and significant association between vendor and accounting firm and AIS effectiveness in small and medium manufacturing enterprises (SMEs) in Malaysia.

\section{Research Hypotheses}

From the overview of the above studies on factors affecting the quality of accounting information systems, it can be seen that the factors affecting the quality of accounting information systems are quite diverse but the studies have not yet been concluded which factors have the strongest influence on the quality of accounting information. At the same time, studies in Vietnam with this topic are very limited in recent years. Therefore, the article presents the following research hypotheses:

$\mathrm{H}_{1}$ : Organization culture has a positive influence on the quality of accounting information system in non-financial listed companies in Vietnam.

$\mathrm{H}_{2}$ : Information technology has a positive influence on the quality of accounting information system in non-financial listed companies in Vietnam.

$\mathrm{H}_{3}$ : Applications in accounting system has a positive influence on the quality of accounting information system in non-financial listed companies in Vietnam.

$\mathrm{H}_{4}$ : Manager participation has a positive influence on the quality of accounting information system in non-financial listed companies in Vietnam.

$\mathrm{H}_{5}$ : Manager knowledge of accounting has a positive influence on the quality of accounting information system in non-financial listed companies in Vietnam.

$\mathrm{H}_{6}$ : Manager knowledge of information technology has a positive influence on the quality of accounting information system in non-financial listed companies in Vietnam.

$\mathrm{H}_{7}$ : User training has a positive influence on the quality of accounting information system in non-financial listed companies in Vietnam.

$\mathrm{H}_{8}$ : Consulting from experts has a positive influence on the quality of accounting information system in non-financial listed companies in Vietnam.

\section{Research Methodology}

\subsection{Data Collection}

Research data was collected through a survey sent via email of 174 industrial companies listed on the Hanoi Stock Exchange. The survey started from March, 2019 to August, 2019. As of March 2019, according to the statistics provided by FiinGroup - one of the leading financial and business information providers in Vietnam, there are 174 industrial companies listed on the Hanoi Stock Exchange. According to research by Haddad and Atmeh (2009), the survey questionnaire via email was sent to the General Director, Chief Financial Officer and Chief Accountant of 174 companies. The authors collected information from FiinGroup to send the questionnaire survey. Thus, the numbers of people who were sent survey questionnaire were 522. The research team reviewed cases of mail not being sent due to an error in the recipient's email address with the wrong name and sent back and making sure the number of messages sent to the correct email address was 522 people. After sending the questionnaire for 2 months, as of May 2019, the authors received 102 responses. The authors continued to send a second email to remind those who had not responded, and by July 2019 , the authors received 165 additional replies, and in August 2019 received 80 additional responses. Thus, total answered forms received by research team were 347 so that the responded rate was about $66 \%$. According to Hair et al. (2010), the minimum number of samples to ensure the quality of quantitative survey is calculated according to the formula: 
Minimum number of samples $=50+5 \times$ number of independent variables

According to this study, the number of independent variables is 8 so the minimum number of samples will be 90 samples. Therefore, with a sample of 347 variables selected, the number of samples was suitable for the survey to ensure quality. The questionnaire consists of 2 parts: (1) The quality of accounting information system; (2) Factors affecting the quality of accounting information system. The questions are designed to convey the opinions from Strongly Disagree, Disagree, Neutral, Agree, Strongly Agree with scores given from 1 to 5 points (Strongly Disagree $=1$ and Strongly agree $=5$ )

\subsection{Research Models}

This paper studies the determinants of the quality of accounting information system. Research model is shown in Fig. 1.

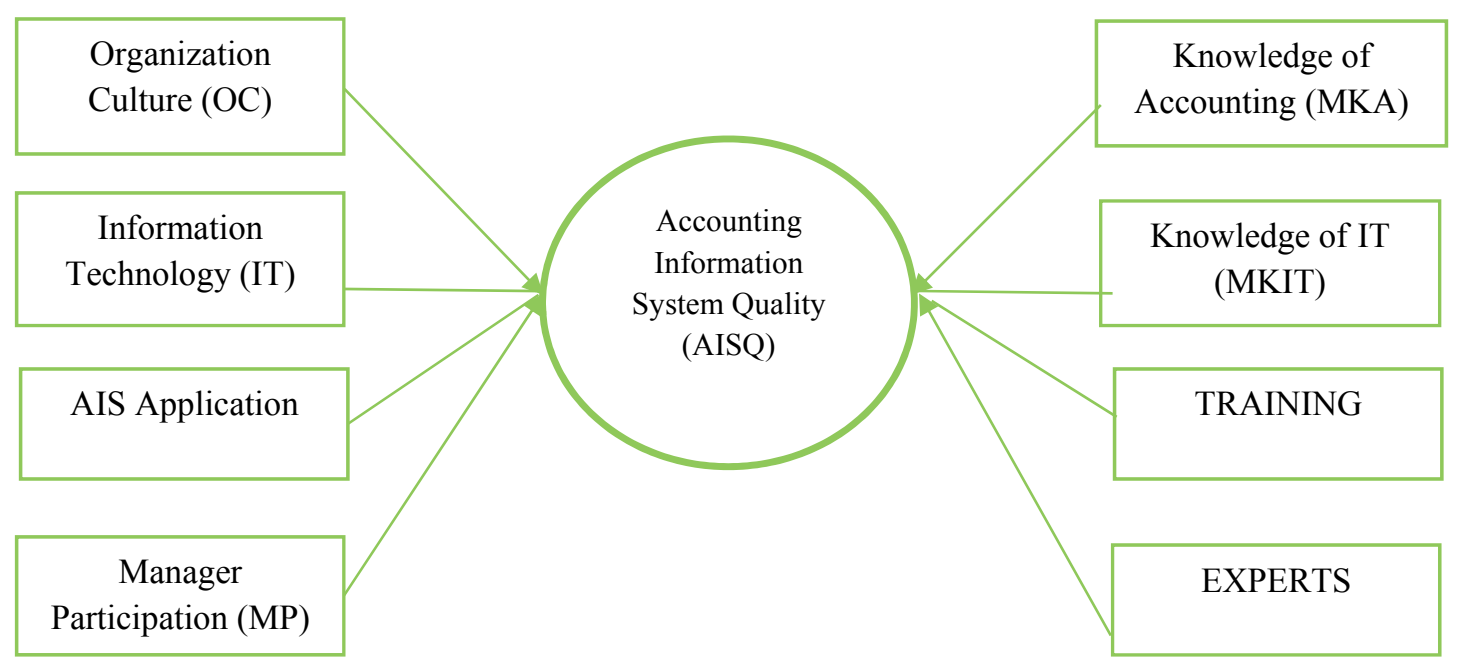

Fig. 1. Accounting information system quality research model

Research model was described as follows:

$\mathrm{AISQ}_{\mathrm{i}}=\alpha_{0}+\alpha_{1} \mathrm{OC}_{\mathrm{i}}+\alpha_{2} \mathrm{IT}_{\mathrm{i}}+\alpha_{3} \mathrm{AISA}_{\mathrm{i}}+\alpha_{4} \mathrm{MP}_{\mathrm{i}}+\alpha_{5} \mathrm{MKIT}_{\mathrm{i}}+\alpha_{6} \mathrm{MKA}_{\mathrm{i}}+\alpha_{7}$ TRAINING $_{\mathrm{i}}+\alpha_{8}$ EXPERTS $_{\mathrm{i}}+€$

Of which:

AISQ $_{\mathrm{i}}$ : Accounting information systems quality of firm $\mathrm{i}$

$\mathrm{OC}_{\mathrm{i}}$ : Organization culture of firm $\mathrm{i}$

IT $_{\mathrm{i}}$ : Information technology of firm $\mathrm{i}$

AISA $_{i}$ : Accounting information applications of firm i

$\mathrm{MP}_{\mathrm{i}}$ : Manager Participation of firm i

$\mathrm{MKA}_{\mathrm{i}}$ : Manager knowledge of accounting of firm $\mathrm{i}$

MKIT $_{\mathrm{i}}$ : Manager knowledge of information technology of firm i

TRAINING $_{\mathrm{i}}$ : Training for users of firm $\mathrm{i}$

EXPERTS $_{\mathrm{i}}$ : Consulting from experts of firm i

The variables and descriptions of variables are shown in Table 1 below: 
Table 1

Summary of research factors

\begin{tabular}{|c|c|c|c|c|}
\hline No & Variables & Definition & Measurement Factor & Previous studies \\
\hline \multicolumn{5}{|c|}{ Independent Variables } \\
\hline 1 & $\begin{array}{l}\text { Organization } \\
\text { Culture (OC) }\end{array}$ & $\begin{array}{l}\text { Organization Culture } \\
\text { is the culture of a } \\
\text { group, is a pattern of } \\
\text { assumptions which } \\
\text { learned by a group to } \\
\text { solve problems of } \\
\text { external adaptation } \\
\text { and internal } \\
\text { integration is carried } \\
\text { out for consider and } \\
\text { then introduced at } \\
\text { organization members. } \\
\text { Characteristics of the } \\
\text { organizational culture } \\
\text { includes attention to } \\
\text { detail, innovation, } \\
\text { team orientation, } \\
\text { outcome orientation } \\
\text { and aggressiveness }\end{array}$ & $\begin{array}{l}\text { Re-examine in detail the work that has been done or } \\
\text { will be done. (OC1) } \\
\text { Use available data, users do work analysis } \\
\text { appropriately. (OC2) } \\
\text { Make tricks/with its own way in deciding an action to } \\
\text { complete the job as the responsibility (OC3) } \\
\text { Do trial and error to improve the quality of work that is } \\
\text { performed. (OC4) } \\
\text { Work in teams rather than individually. (OC5) } \\
\text { Do the work in collaboration with other teams (other } \\
\text { divisions). (OC6) } \\
\text { Convince that any work undertaken will achieve the } \\
\text { expected results. (OC7) } \\
\text { The activities which were undertaken give high hopes } \\
\text { to the system users to obtain maximum results. (OC8) } \\
\text { Have the initiative to do the work in advance without } \\
\text { waiting for work team to perform a task. (OC9) } \\
\text { Compare the work results that were performed to } \\
\text { others' work results in reaching the work targets as the } \\
\text { responsibility (OC10) }\end{array}$ & $\begin{array}{l}\text { McShane and } \\
\text { Glinow (2010) }\end{array}$ \\
\hline 2 & $\begin{array}{l}\text { Information } \\
\text { Technology (IT) }\end{array}$ & $\begin{array}{l}\text { IT is a construct which } \\
\text { refers to the nature, } \\
\text { complexity and } \\
\text { interdependence of IT } \\
\text { usage and } \\
\text { management in an } \\
\text { organization. IT } \\
\text { includes: Office } \\
\text { Support Systems, } \\
\text { Decision Support } \\
\text { System, data base } \\
\text { system, computer- } \\
\text { aided design, } \\
\text { computer-aided } \\
\text { manufacturing and } \\
\text { computer-assisted } \\
\text { production } \\
\text { management }\end{array}$ & $\begin{array}{l}\text { Office Support Systems (word processing, graphics, and } \\
\text { presentation packages) (IT1) } \\
\text { Decision Support Systems (spreadsheets and similar) } \\
\text { (IT2) } \\
\text { Database Systems (personnel and other non-accounting } \\
\text { systems) (IT3) } \\
\text { Accounting-Based Applications (payroll, receivables, } \\
\text { payables, general ledger, order entry and billing) (IT4) } \\
\text { Computer-Assisted Production Management (inventory } \\
\text { management, raw materials purchasing, production } \\
\text { planning and control) (IT5) } \\
\text { Computer-Aided Design (This system facilitates the } \\
\text { creation and manipulation of industrial drawings) (IT6) } \\
\text { Computer-Aided Manufacturing (This system } \\
\text { automates production by computer operation of } \\
\text { numerically controlled machine tools) (IT7) } \\
\text { Local Area Network (LAN) (Communication system } \\
\text { which interconnects computers within an organization } \\
\text { such as local e-mail, application and data sharing) (IT8) } \\
\text { External Network (Communication system that } \\
\text { interconnects computers at geographically dispersed } \\
\text { location such as Internet, Electronic Data Interchange } \\
\text { and external data sources) (IT9) }\end{array}$ & $\begin{array}{l}\text { Ismail (2009); } \\
\text { Tamoradi (2014) }\end{array}$ \\
\hline 3 & $\begin{array}{l}\text { Accounting } \\
\text { Information } \\
\text { System } \\
\text { Application } \\
\text { (AISA) }\end{array}$ & $\begin{array}{l}\text { Accounting } \\
\text { Information System } \\
\text { applications (AISA) } \\
\text { are set of procedures } \\
\text { such as: General } \\
\text { ledger, billing, } \\
\text { budgeting, order entry, } \\
\text { project management, } \\
\text { purchasing, cost } \\
\text { accounting, } \\
\text { production variances, } \\
\text { inventory, budget } \\
\text { variances, production } \\
\text { planning and control, } \\
\text { Financial analysis }\end{array}$ & $\begin{array}{l}\text { General ledger (AISA1) } \\
\text { Cost accounting (AISA2) } \\
\text { Accounts receivable (AISA3) } \\
\text { Financial accounting (AISA4) } \\
\text { Accounts payable AISA5) } \\
\text { Financial analysis (AISA6) } \\
\text { Billing (AISA7) } \\
\text { Budgeting Order entry (AISA8) } \\
\text { Project management (AISA9) } \\
\text { Purchasing (AISA10) } \\
\text { Production variances (AISA11) } \\
\text { Inventory (AISA12) } \\
\text { Budget variances (AISA13) } \\
\text { Production planning and control (AISA14) } \\
\text { Modeling (AISA15) } \\
\text { Payroll (AISA16) } \\
\text { Personnel management (AISA17) }\end{array}$ & $\begin{array}{l}\text { Tamoradi (2014); } \\
\text { Ismail (2009) }\end{array}$ \\
\hline 4 & $\begin{array}{l}\text { Manager } \\
\text { Participation } \\
(\mathrm{MP})\end{array}$ & $\begin{array}{l}\text { Manager Participation } \\
\text { (MP) is the } \\
\text { involvement and } \\
\text { efforts of managers to } \\
\text { maintain behaviors to } \\
\text { help others achieve } \\
\text { their goals }\end{array}$ & $\begin{array}{l}\text { Definition of needs (MP1) } \\
\text { Choice of hardware and software (MP3) } \\
\text { Implementation of systems (MP2) } \\
\text { Solving problems since implementation (MP4) } \\
\text { Planning of further developments (MP5) }\end{array}$ & $\begin{array}{l}\text { Guinea et al. } \\
(2005) ; \\
\text { Jarvenpaa and } \\
\text { Ives (1991); } \\
\text { Ismail (2009); } \\
\text { Alnajjar (2016); } \\
\text { Tamoradi (2014) }\end{array}$ \\
\hline
\end{tabular}


192

\begin{tabular}{|c|c|c|c|c|}
\hline 5 & $\begin{array}{l}\text { Manager } \\
\text { Knowledge of } \\
\text { Accounting } \\
\text { (MKA) }\end{array}$ & $\begin{array}{l}\text { Manager Knowledge } \\
\text { of Accounting (MKA) } \\
\text { represents ability of } \\
\text { manager to understand } \\
\text { techniques in financial } \\
\text { accounting, } \\
\text { Management } \\
\text { accounting as well as } \\
\text { Tax accounting. }\end{array}$ & $\begin{array}{l}\text { Financial accounting techniques (MKA1) } \\
\text { Management accounting techniques (MKA2) } \\
\text { Tax accounting techniques (MKA3) }\end{array}$ & $\begin{array}{l}\text { Ismail (2009); } \\
\text { Tamoradi (2014) }\end{array}$ \\
\hline 6 & $\begin{array}{l}\text { Manager } \\
\text { Knowledge of } \\
\text { Information } \\
\text { Technology } \\
\text { (MKIT) }\end{array}$ & $\begin{array}{l}\text { Manager Knowledge } \\
\text { of Information } \\
\text { Technology (MKIT) } \\
\text { represents ability to } \\
\text { use a list of } \\
\text { applications such as } \\
\text { word-processing, } \\
\text { Spreadsheet package, } \\
\text { Database package, } \\
\text { Accounting-based } \\
\text { applications, } \\
\text { Computer-assisted } \\
\text { production } \\
\text { management and net } \\
\text { work }\end{array}$ & $\begin{array}{l}\text { Word-processing package (MKIT1) } \\
\text { Spreadsheet package (MKIT2) } \\
\text { Database package (MKIT3) } \\
\text { Accounting-based applications (MKIT4) } \\
\text { Computer-assisted production management (MKIT5) } \\
\text { Local Network (MKIT6) } \\
\text { External Network (MKIT7) }\end{array}$ & $\begin{array}{l}\text { Ismail (2009); } \\
\text { Tamoradi (2014) }\end{array}$ \\
\hline 7 & $\begin{array}{l}\text { Users } \\
\text { Training } \\
\text { (TRAINING) }\end{array}$ & $\begin{array}{l}\text { Training } \\
\text { (TRAINING) is } \\
\text { organized activities to } \\
\text { enhance the } \\
\text { knowledge and skills } \\
\text { of the people to } \\
\text { achieve certain goals }\end{array}$ & $\begin{array}{l}\text { Analyze the training need (TRAINING 1) } \\
\text { Design the overall training program (TRAINING 2) } \\
\text { Develop the course (actually assembling/creating } \\
\text { training materials) (TRAINING 3) } \\
\text { Implementing training (TRAINING 4) } \\
\text { Evaluate course effectiveness (TRAINING 5) }\end{array}$ & Dessler (2013) \\
\hline 8 & $\begin{array}{l}\text { Consulting } \\
\text { from experts } \\
\text { (EXPERTS) }\end{array}$ & $\begin{array}{l}\text { Consulting from } \\
\text { experts (EXPERTS) } \\
\text { are advice and } \\
\text { comment or } \\
\text { recommendations } \\
\text { from external experts }\end{array}$ & $\begin{array}{l}\text { Consultants (EXPERTS 1) } \\
\text { Vendors/Dealers (EXPERTS 2) } \\
\text { Government agencies (EXPERTS 3) } \\
\text { Accounting firms (EXPERTS 4) }\end{array}$ & Ismail (2009) \\
\hline \multicolumn{5}{|c|}{ Dependent Variables } \\
\hline 9 & $\begin{array}{l}\text { Accounting } \\
\text { Information } \\
\text { Systems } \\
\text { Quality } \\
\text { (AISQ) }\end{array}$ & $\begin{array}{l}\text { Accounting } \\
\text { Information Systems } \\
\text { Quality (AISQ) are } \\
\text { described as: } \\
\text { integration, flexible, } \\
\text { reliability and } \\
\text { efficient. }\end{array}$ & $\begin{array}{l}\text { Information system which is used is integrated with } \\
\text { other departments in the local office (AISQ1) } \\
\text { Easy to access the necessary data. (AISQ2) } \\
\text { Be able to make company more competitive } \\
\text { (competition). (AISQ3) } \\
\text { Obtain the information without having to contact the } \\
\text { one in data processing. (AISQ4) } \\
\text { Access the information system while outside of the } \\
\text { office and was in other department rooms. (AISQ5) } \\
\text { Can quickly be adapted to work (AISQ6) } \\
\text { Has an input option based on the work need. (AISQ7) } \\
\text { Have selection report based on the needs required. } \\
\text { (AISQ8) } \\
\text { Meets the needs based on the undertaken authority and } \\
\text { responsibility. (AISQ)9 } \\
\text { Can be relied on to take a decision based on the } \\
\text { authority and responsibility. (AISQ10) } \\
\text { obtain various reports from the same data input. } \\
\text { (AISQ11) } \\
\text { Has a rapid response in producing a report (not slow). } \\
\text { (AISQ12) } \\
\text { Save data with small capacity, without spending large } \\
\text { memory. (AISQ13) } \\
\text { Simply conducts backup data. (AISQ14) } \\
\text { Each work that is performed has predetermined time } \\
\text { completion. (AISQ15) }\end{array}$ & $\begin{array}{l}\text { Wixom and Todd } \\
(2005) ; \\
\text { Heidmann et al. } \\
\text { (2008); Ong et al. } \\
\text { (2009); Chang et } \\
\text { al. (2012) }\end{array}$ \\
\hline
\end{tabular}

Source: Compiled by the authors

\subsection{Research Design}

Data analysis methods used in the article include:

Firstly, testing the reliability of the scale: Results of analysing the reliability of the scale based on two criteria on Cronbach's Alpha coefficient $>0.6$ and the correlation coefficient of the total variables of the observed variables must be greater than 0.3 
Secondly, explore factor analysis. Factor analysis indicates the analysis results are appropriate when KMO coefficients are greater than 0.5 and the total variance explained is greater than $50 \%$.

Thirdly, statistical description to express general information about variables.

Fourth, test the correlation between variables. The correlation coefficient indicates the relationship between the two study variables, the higher the correlation coefficient, the more closely the two variables are related.

Fifth, regression analysis. The results of regression analysis with the dependent variables, in turn, are the quality of the accounting information system and the performance of the whole enterprise.

\section{Results and Discussion}

\subsection{Testing the reliability of the scale}

The analysis results show that the factors OC, MP, MKA and TRAINING are all reliable with the initial observed variables (Cronbach's Alpha coefficients are greater than 0.6 and the smallest correlation coefficients are greater than 0.3 ). The remaining factors all need to eliminate unnecessary observation variables (unnecessary observation variables when the total correlation coefficient is less than 0.3). Detailed results of excluded observed variables (Items deleted) are shown in the Table 2 below:

\section{Table 2}

Testing the reliability of the scale

\begin{tabular}{llll}
\hline Variables & Cronbach's Alpha & $\begin{array}{l}\text { Total Correlation } \\
\text { Coefficient }\end{array}$ & Items deleted \\
\hline OC & .946 & .660 & \\
MP & .884 & .563 & - \\
MKIT & .728 & 422 & MKIT1, MKIT4 \\
MKA & .679 & .434 & - \\
TRAINING & .761 & .435 & - \\
EXPERTS & .694 & .538 & EXPERTS3 \\
AISQ & .869 & .396 & AISQ10, AISQ11 AISQ12, AISQ13, \\
& & & AISQ14, AISQ15, AISQ16 \\
\hline
\end{tabular}

Source: Data processing results of authors

\subsection{Results of explore factor analysis}

Factor analysis indicates the analysis results are appropriate when KMO coefficients are greater than 0.5 ; total analytical variance is greater than $50 \%$. With two factors AISA and IT are measured directly through a question. Therefore, these two factors will not be included in the scale reliability analysis nor the factor analysis (only factors measured from multiple observed variables will be included in the scale reliability analysis. measurement and factor analysis). Two factors AISA and IT will be included in the regression analysis.

\section{Table 3}

Results from explore factors analysis

\begin{tabular}{lrrr}
\hline Variables & KMO's coefficient & General variance explained & Numbers of factors \\
\hline OC & .930 & $68.23 \%$ & 1 \\
MP & .811 & $69.31 \%$ & 1 \\
MKIT & .644 & $55.19 \%$ & 1 \\
MKA & .646 & $64.00 \%$ & 1 \\
TRAINING & .607 & $51.74 \%$ & 1 \\
EXPERTS & .700 & $71.07 \%$ & 1 \\
AISQ & .853 & $53.70 \%$ & 1 \\
\hline
\end{tabular}

\subsection{Descriptive Statistics}

Source: Data processing results of authors

Through the statistical description table, the authors assess the status of the influence of factors on the quality of accounting information systems as well as the performance of enterprises. 
Table 4

Descriptive Statistics

\begin{tabular}{lccccc}
\hline \multicolumn{1}{c}{ Variables } & $\mathrm{N}$ & Minimum & Maximum & Mean & Std. Deviation \\
\hline AISQ & 376 & 2.67 & 4.89 & 3.8088 & .34805 \\
OC & 376 & 1.00 & 5.00 & 3.6684 & .63084 \\
MP & 376 & 2.20 & 5.00 & 3.6197 & .76798 \\
MKIT & 376 & 2.00 & 4.75 & 3.1363 & .61850 \\
MKA & 376 & 3.00 & 5.00 & 4.4397 & .47257 \\
TRAINING & 376 & 2.40 & 5.00 & 3.7766 & .57973 \\
EXPERTS & 376 & 1.00 & 5.00 & 3.4681 & .66989 \\
IT & 376 & 5 & 9 & 7.90 & 1.042 \\
AISA & 376 & 10 & 16 & 14.32 & 2.010 \\
\hline
\end{tabular}

Statistical results show the impact of factors at an average level where the managers' knowledge of accounting (MKA) is rated the best (average 4.4 on a 5-point scale), information technology (IT) is being ranked the second best average score of 7.9 on the 9-point scale, AIS applications (AISA) is also rated at the third best with an average score of 14.32 on the 18-point scale.

\subsection{Correlation Analysis}

Results from the correlation coefficient matrix indicate that the AISQ variable has the strongest correlation with the OP (correlation coefficient is 0.767) and the weakest correlation with the EXPERTS variable (correlation coefficient is equal to 0.085 ). The independent variables in the model have correlation coefficients less than 0.8 , so almost no collinear phenomenon occurs.

Table 5

Correlation Matrix

\begin{tabular}{lcccccccc}
\hline & AISQ & OC & MP & MKIT & MKA & TRAINING & EXPERTS & IT \\
\hline AISQ & 1 & & & & & & & \\
OC & $.363^{* *}$ & 1 & & & & & \\
MP & $.412^{* *}$ & $.133^{* *}$ & 1 & & & & \\
MKIT & $.327^{* *}$ & $.112^{*}$ & -.033 & 1 & & & \\
MKA & $.552^{* *}$ & $.195^{* *}$ & .052 & -.038 & 1 & & \\
TRAINING & $.194^{* *}$ & $.141^{* *}$ & $.134^{* *}$ & .093 & .051 & 1 & .037 & .036 \\
EXPERTS & .085 & $.203^{* *}$ & -.010 & -.064 & -.011 & .011 & $.136^{* *}$ \\
IT & $.601^{* *}$ & $.222^{* *}$ & .018 & -.043 & $.417^{* *}$ & .003 & $.600^{* *}$ \\
AISA & $.494^{* *}$ & $.247^{* *}$ & -.001 & $-.102^{*}$ & $.257^{* *}$ & $.105^{*}$ & 1 \\
\hline
\end{tabular}

**. Correlation is significant at the 0.01 level (2-tailed).

*. Correlation is significant at the 0.05 level (2-tailed).

\subsection{Regression results and discussion}

Through regression analysis, multicollinearity test results are all VIF values less than 10 , so there are no collinearities in the model.

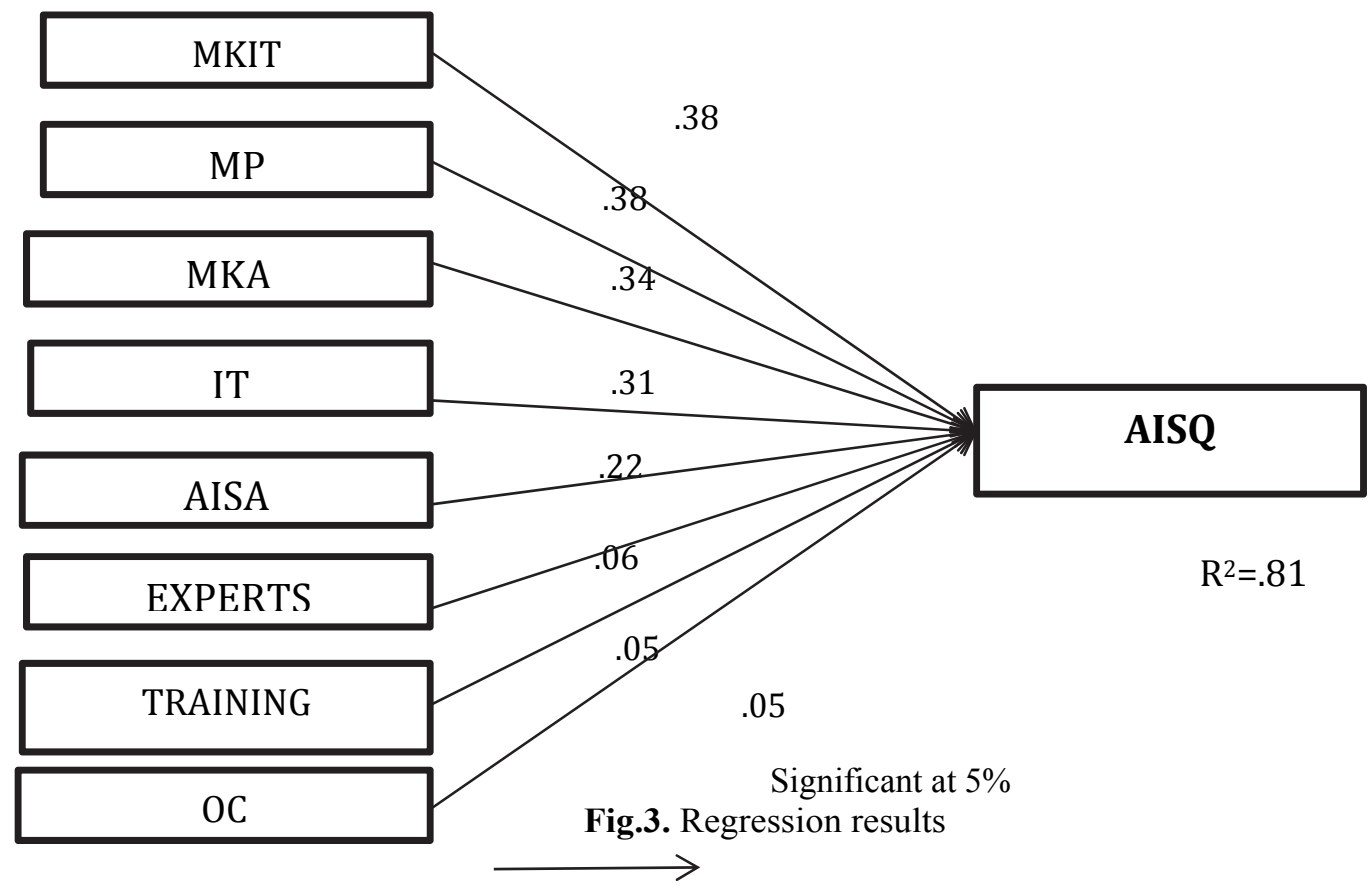


According to the statistics given in Fig.3., it has been indicated that: MP, AIS, IT, MKIT, MKA, EXPERT, TRAINING and OC had positive effects on AISQ ( $\mathrm{p}$-value is less than 0.05 and positive regression coefficient). Coefficient value of $\mathrm{R}^{2}=$ 0.81 of AIS quality model represents that the independent variables in the model explain $81 \%$ of the variation of the dependent variable

The influence of factors on the quality of accounting information systems summarized in Table 6 :

Table 6

Regression Coefficient of accounting information system quality research model

\begin{tabular}{clcl}
\hline No & Variables & Regression Coefficient & Effect sign \\
\hline 1 & MKIT (Manager Knowledge of IT) & 0.38 & + Positive \\
2 & MP (Manager Participation) & 0.38 & + Positive \\
3 & MKA (Manager Knowledge of Accounting) & 0.34 & + Positive \\
4 & IT (Information Technology) & 0.31 & + Positive \\
5 & AISA (Accounting Information Applications) & 0.22 & + Positive \\
6 & EXPERTS (Consultants from experts) & 0.06 & + Positive \\
7 & TRAINING (Training for users) & 0.05 & + Positive \\
8 & OC (Organization Culture) & 0.05 & + Positive \\
\hline
\end{tabular}

Source: Data processing results of authors

Regression results in Table 6 indicated that:

(i) Hypothesis 1: Organization culture has a positive influence on the quality of accounting information system in nonfinancial listed companies in Vietnam was accepted. This result supported for research results of Rapina (2014)

(ii) Hypothesis 2: Information technology has a positive influence on the quality of accounting information system in non-financial listed companies in Vietnam was accepted. This result supported for research results of Haddad and Atmeh (2009) but inconsistent with the research results of Ismail and King (2007) Tamoradi (2014)

(iii) Hypothesis 3: Applications in accounting system has a positive influence on the quality of accounting information system in non-financial listed companies in Vietnam was accepted. This result shared the same opinion with Tamoradi (2014) but disagreed with Ismail (2009)

(iv) Hypothesis 4: Manager participation has a positive influence on the quality of accounting information system in non-financial listed companies in Vietnam was accepted. This result contributed empirical evidences supporting participation of managers to usefulness of AIS with Thong et al., 1996; Igbaria et al., 1997; Foong, 1999; Guinea et al., 2005; Tamoradi (2014); Alnajjar (2016). However, is not reinforced by the arguments from Ismail (2009)

(v) Hypothesis 5: Manager knowledge of accounting has a positive influence on the quality of accounting information system in non-financial listed companies in Vietnam was accepted. This result totally agreed with the results of Ismail and King (2007); Saeidi (2014), Alnajjar (2016) stated that managers with accounting knowledge are in a better position than those without the knowledge.

(vi) Hypothesis 6: Manager knowledge of information technology has a positive influence on the quality of accounting information system in non-financial listed companies in Vietnam was accepted. This conclusion is in consent with Hussin et al. (2002); Ismail and King (2007); Tamoradi (2014)

(vii) Hypothesis 7: User training has a positive influence on the quality of accounting information system in non-financial listed companies in Vietnam was accepted. This result reaffirmed conclusion about the positive effect of user training and the accounting information system quality in Fitrios (2016)

(viii) Hypothesis 8: Consulting from experts has a positive influence on the quality of accounting information system in non-financial listed companies in Vietnam was accepted. This result is consistent with Breen and Sciulli (2002), Hartcher (2003), Berry et al. (2006) and Ismail (2009) showing accountants, accounting profession, industry associations and AIS training professionals played important roles in encouraging SMEs to computerize their accounting systems.

\section{Conclusion and Recommendations}

\subsection{Conclusion}

Core objective of AIS was to collect and record data and information associated with event that can economically impact on firms. It processed data and communicate this information to both external and internal stakeholders. This paper has conducted a survey to investigate factors affecting the quality of accounting information systems pointed out that factors such as organizational culture (OC), accounting information applications (AISA), experts (EXPERTS) and user training (TRAINING), managers' accounting knowledge (MKA), managers' IT knowledge (MKIT), information technology (IT), and participation of managers (MP) were statistically significant at 5\% level to the quality of accounting information 
systems. These factors explain up to $81 \%$ of the fluctuations in the quality of accounting information systems $\left(\mathrm{R}^{2}\right.$ value $=81 \%$ ). Among those influential factors, manager IT knowledge (MKIT), information technology, management participation (MP), manager accounting knowledge (MKA) were the most powerful factors. Regression coefficient value of MKIT, MKA and MP are 0.38 ; 0.38 and 0.34 respectively. This study complements previous research by having supported this association within Vietnamese context. Further studies may replicate this study to enhance the external validity of the results.

\subsection{Recommendations}

From the research results drawn above, the authors make the following suggestions to improve the quality of accounting information systems for companies listed on the stock exchange in Vietnam as follows:

Firstly, fostering knowledge on accounting for managers. Being a manager, it is necessary to have clear understanding of the business activities. Accounting is the language of business and from this research result, accounting knowledge is the most important element of AIS quality. Therefore, managers need to have good knowledge of accounting in order to know the business situation, from which they can run a good business operation and bring high profits to the business. Managers need to acquire sufficient accounting knowledge. Company should also have policies that encourage managers to take short accounting courses with topics relevant to the business management like managerial accounting, tax accounting, internal control, etc. so that the manager will be proactive in managing the accounting information system.

Secondly, enhancing information technology knowledge for managers. The knowledge is viewed as the primary determining factor of organizational success and is considered the foundation of competitive advantage. Manager should learn basic knowledge of computer science, software technology, computer engineering, information systems, computer and communications networks, and network information security. In addition, the specialized knowledge should be provided such as: research, development, processing or application of software systems; design, construction, installation, operation and maintenance of hardware and software components of computer systems and computer-based equipment systems; computer networks and communications.

Thirdly, invest in innovation and application of modern information technology at companies. Firms with extensive resources may gain a competitive edge by deploying IT in support of or to strengthen their business (King et al., 1989). Information technology includes computers and computer software to convert, store, protect, process, transmit and collect information in order to develop the ability to repair, create and systems devices to provide information processing solutions based on personal and organizational technology required.

Fourth, promote the participation of managers in all stages of work to develop the accounting information system. Managers should participate regularly and continuously in all jobs to build, operate and develop the system such as determining the need of developing accounting information systems and controlling information system. The involvement of managers in the planning, construction and operation of accounting information systems is both motivating, encouraging employees' work and supervising to system operate effectively.

Fifth, open training classes for users of accounting information systems. The users of the accounting information system are quite diverse, including accountants, sales staff, production department, and material supply staff. The employees in the system need to understand their responsibilities in the system and the relationship between their work and the work of others in the system. The irresponsibility or carelessness of a person in the system seriously affects the operation of the system. Therefore, the training needs to be conducted periodically to ensure that all people in the system are proficient in using the system, updating the system's new points to make the system operate smoothly and bring high efficiency.

Finally, recruitment of information technology qualified personnel

As a graduate of Information technology who qualified can become a software developer that directly creates the software products, quality control of software that directly testing the quality of products created by the programmer, analyst system design, data management, network management, computer hardware engineering and specialist in management and coordination of information technology projects.

\section{References}

Alnajjar, M. (2016). Impact of Accounting Information System on Organizational Performance: A Study of Small and MidSized Enterprises in UAE. International Journal of Accounting Research, 4(1),1-7.

Azhar Susanto. (2008). Sistem Informasi Akuntansi. Struktur-Pengendalian Resiko-Pengembangan. Bandung: Lingga Jaya. 
Berry, J.A., Sweeting, R. and Goto, J. (2006). The Effects of Business Advisers on the Performance of SMEs. Journal of Small Business and Enterprise Development, 13(1), 33-47.

Bodnar, G.H., \& dan Hopwood,W.S. (2010). Accounting Information Systems. Ninth Edition. USA: Pearson Education, Inc

Breen, J., Sciulli, N., \& Calvert, C. (2004). The role of the external accountant in small firms. Small Enterprise Research, 12(1), 5-14.

Chang, C.-S., Chen, S.-Y., \& Lan, Y.-T. (2012). Motivating medical information system performance by system quality, service quality, and job satisfaction for evidence based practice. BMC Medical Informatics and Decision Making, 12(135), 1-12.

Choe, J.M. (1998). The Effects of User Participation on design of Accounting Information System. Information and Management, 34, 185-198

Chan, Y., Huff, S., Barclay, D., and Copeland, D. (1997). Business Strategic Orientation, Information Strategic Organization, and Strategic Alignment. Information Systems Research, 8(2), 125-150.

Davis, M. (1997). Transforming your firm: Tools for successful technology consulting. The Practical Accountant, $30(8)$, S-3.

Dessler, G. (2013). Fundamentals of human resource management. Pearson.

Fitrios, R. (2016). Factors that influence accounting information system implementation and accounting information quality. International Journal of Scientific \& Technology Research, 5, 193-198.

Foong, S.Y. (1999). Effect of end-user personal and systems attributes on computer-based information system success in Malaysian SMEs. Journal of Small Business Management, 37(3), 81-87.

Grande, E. U., Estébanez, R. P., \& Colomina, C. M. (2011). The impact of Accounting Information Systems (AIS) on performance measures: empirical evidence in Spanish SMEs. The international journal of digital accounting research, 11(1577-8517), 25-43.

Gullkvist, B. (2002). Towards Paperless Accounting and Auditing. E-Business Research Center, Finland.

Guinea, AO, Kelley, H \& Hunter, MG. (2005). Information system effectiveness in small business: Extending a Singaporean model in Canada. Journal of Global Information Management, 13(3), 55-70.

Hair, J., Black, W. C., Babin, B. J., \& Anderson, R. E. (2010). Multivariate data analysis (7th ed.). Upper saddle River, New Jersey: Pearson Education International.

Heidmann, M., Schäffer, U., \& Strahringer, S. (2008). Exploring the role of management accounting systems in strategic sensemaking. Information Systems Management, 25(3), 244-257.

Hla, D., \& Teru, S.P. (2015), Efficiency of accounting information system and performance measures. International Journal of Multidisciplinary and Current Research, 3, 976984.

Huber, G. P. (1990). A theory of the effects of advanced information technologies on organizational design, intelligence, and decision making. Academy of Management Review, 15(1), pp. 47-71.

Hussin, H., King, M., \& Cragg, P. (2002). IT alignment in small firms. European Journal of Information Systems, 11(2), 108127.

Haddad \& Atmeh. (2009). Accounting information system (1st Ed.). Amman: Al Mareekh.

Hurt, R. L., \& Zhen, F. (2008). Accounting information systems: Basic concepts and current issues. McGraw-Hill Irwin.

Hartcher, J. (2003). Small Business Survey Program: Financial Management. Insolvency and Fraud, CPA Australia.

Igbaria, M., Zinatelli, N., Cragg, P.B., \& Cavaye, A.L.M. (1997). Personal computing acceptance factors in small firms: A structural equation model, MIS Quarterly, 21(3), 279-305.

Ismail, N.A (2009). Factors influencing AIS effectiveness among manufacturing SMEs: Evidence from Malaysia. The Electronic Journal on Information Systems in Developing Countries, 38(10), 1-19.

Ismail, N. A., \& King, M. (2014). Factors influencing the alignment of accounting information systems in small and medium sized Malaysian manufacturing firms. Journal of Information Systems and Small Business, 1(1-2), 1-20.

Jarvenpaa, S. L., \& Ives, B. (1991). Executive involvement and participation in the management of information technology. MIS quarterly, 15(2), 205-227.

Kouser, R., Awan, A., Rana, G., \& Shahzad, F. (2011). Firm size, leverage and profitability: Overriding impact of accounting information system. Journal of Management and Business Review, 1(10), 58-64.

Kaplan, R.S., \& Atkinson, A.A. (1998). Advanced management accounting (3rd ed.). New Jersey: Prentice Hall International.

Kharuddin, S., Ashhari, Z., and Nassir, A., (2010). Information systems and firm's performance: The case of Malaysian small medium enterprises, International Business Research, 3(4), 28-35.

King, W. R., Grover, V., \& Hufnagel, E. H. (1989). Using information and information technology for sustainable competitive advantage: some empirical evidence. Information \& Management, 17(2), 87-93.

Laudon, K.C., \& Laudon, J.P. (2007). Management Information Systems Managing The Digital Firm. 10 ${ }^{\text {th }}$ Edition. Pearson Prentice Hall.

McShane, S.L., \& Glinow, M.A.V. (2010). Organizational behavior: Emerging knowledge and practice for the real world (5th ed.). New York: Mc Graw Hill.

Napitupulu, I.H. (2018). Organizational culture in management accounting information system: Survey on state-owned enterprises (SOEs) Indonesia. Global Business Review, 19, 556-571.

Nwinee, K., Akpos, Y., Vincent, N., \& Ibinabo, T. (2016). Impact of accounting information system on organizational effectiveness: A study of selected small and medium scale enterprises in Woji, Portharcourt. International Journal of 
Research, 3(1), 974-982.

Nabizadeh, S.M., \& Omrani, S.A. (2014). Effective factors on accounting information system alignment; A step towards organizational performance improvement. International Journal of Scientific and Research Publications, 4(9), 1-5.

Onaolapo, A.A., Odetayo, T.A. (2012). Effect of accounting information system on organisational effectiveness: A case study of selected construction companies in Ibadan, Nigeria. American Journal of Business and Management, 1(4), 183189.

O’Brien, J.A. (2004). Management Information Systems: Managing Information Technology in the Networked Enterprise 6thEdition. NewYork: Mc Graw Hill Companies,Inc

Ong, C.S., Day, M.Y., \& Hsu, W.L. (2009). The measurement of user satisfaction with question answering systems. Information and Management, 46(7), 397-403.

Piccoli, G. (2008). Information Systems for Managers: Text \& Cases. USA: John Wiley \& Sons,Inc

Rapina. (2014). Factors influencing the quality of accounting information system and its implications on the quality of accounting information. Research Journal of Finance and Accounting, 5(2), 148-154.

Raymond, L., \& Pare, G. (1992). Measurement of information technology sophistication in small manufacturing businesses, Information Resources Management Journal, 5(2), 4-16.

Rehab, U. (2018). The impact of accounting information systems on organizational performance: The context of Saudi's SMEs. International Review of Management and Marketing, 8(2), 69-73.

Romney, M. B., \& Steinbart, P. J. (2015). Accounting Informations Systems. Thierteenth Edition. Pearson Education Limited.

Robbins, S.P., \& Judge, T.A. (2011). Organizational Behavior (14ed). Pearson education, Prentice Hall, UPPER Saddle, NJ.

Schein, E.H. (2010). Organizational Culture and Leadership. $4^{\text {th }}$ ed. San Fransisco: Jossey Bass-A Wiley Imprint.

Soudani, S.N. (2012). The usefulness of an accounting information system for effective organizational performance. International Journal of Economics and Finance, 4(5), 136140.

Stair, R.M., \& Reynolds, G.W. (2010). Principles of information systems (9th ed.). Boston, MA: Course Technology.

Stair, R.M. \& Reynolds, G.W. (2012). Information systems. Melbourne: Course Technology; Cengage Learning.

Sajady, H., Dastgir, M., \& Hashemnejad. (2008). Evaluation of the effectiveness of accounting information systems. International Journal of Information Science \& Technology, 6(2), 49-59

Saeidi (2014). The impact of accounting information systems on financial performance - a case study of TCS - India. Indian Journal of Fundamental and Applied Life, 4(4), 412-417

Tamoradi, F. (2014). Factors influencing the alignment of accounting information systems of accepted manufacturing firms in Tehran Stock Exchange. International Journal of Industrial Engineering Computations, 4(3).

Thapayom, A., \& Ussahawanitchakit, P. (2015). Accounting information system excellence and goal achievement: evidence from information and communication technology businesses in Thailand. The Business and Management Review, 6th International Trade and Academic Research Conference (ITARC), 9-10 November 2015, UK, 7(1), 309-321

Thong, J.Y.L., Yap, C.S., \& Raman, K.S. (1996). Top management support, external expertise and information systems implementation in small businesses. Information Systems Research, 7(2), 248-267.

Yap, C.S. and Thong, J.Y.L. (1997). Programme Evaluation of a Government Information Technology Programme for Small Businesses, Journal of Information Technology, 12, 107-120.

Wilkinson, J. W. (2000). Accounting and information systems. John Wiley \& Sons, Inc.

Wixom, B.H., \& Todd, P.A. (2005). A theoretical integration of user satisfaction and technology acceptance. Information Systems Research, 16(1), 85-102

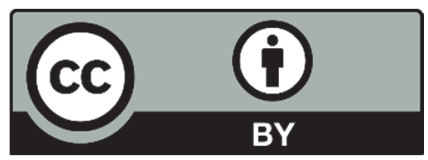

(C) 2020 by the authors; licensee Growing Science, Canada. This is an open access article distributed under the terms and conditions of the Creative Commons Attribution (CC-BY) license (http://creativecommons.org/licenses/by/4.0/). 